\title{
GENE ACTION AND COMBINING ABILITY IN SOME TOMATO (Solanum lycopersicum L.) CROSSES GROWN IN LATE SUMMER SEASON

\author{
Masry $^{2}$, A. I.; A. M. Kansouh ${ }^{2}$; T. A. Shalaby ${ }^{1}$; M. T. Rakha ${ }^{1}$ and
}

A. A. Etman ${ }^{1}$

${ }^{1}$ Horticulture Department, Faculty of Agriculture, Kafrelsheikh University, Kafr El-Sheikh 33516, Egypt

${ }^{2}$ Vegetable Research Department, Horticulture Research institute, Agriculture Research Center, Giza, Egypt.

\begin{abstract}
Gene action and combining ability effects were estimated in forty five hybrids obtained from crossing fifteen lines with three testers using line $x$ tester matting design. These genotypes (fifteen lines, three testers and forty five hybrids) were evaluated for vegetative growth, yield and its quality in late summer season. This study was carried out at Faculty of Agriculture, Kafrelsheikh University, Sidi Salim distrect, North-Delta Region of Egypt. G.C.A and P.C.V. \% ranged from 0.88 to 0.98 , which was confirmed by the estimated ratio of G.C.V. / P.C.V. Furthermore, broad sense heritability ( $h^{2} b s$ ) values ranged from 76.96 to 95.60 suggesting less effect of environmental and the large portion of $\sigma^{2} p$ was due to the $\sigma^{2} g$ on these traits. The magnitude of variance due to general and specific combining ability was highly significant indicating importance of the additive $\left(\sigma^{2} A\right)$ and non-additive $\left(\sigma^{2} D\right)$ gene action. However, the ratios of $\sigma^{2} \mathrm{GCA} / \sigma^{2} \mathrm{SCA}(<1)$ and $\sigma^{2} \mathrm{~A} / \sigma^{2} \mathrm{D}(<1)$ revealed the preponderance of non-additive variance in the inheritance of all studied traits. The average degree of dominance revealed over-dominance for all studied traits except for ascorbic acid content, which was revealed partial dominance. Highly significant differences were observed among the parents and hybrids for general combining ability (GCA) and specific combining ability (SCA) effects. The parental lines HE-13-21, HE-6-5-1, HE-13-1-1 and D-7-3-1 displayed desirable general combiners for most studied traits. The cross combinations HE-13-1-1 x F.M.9, D-4-3-1 x F.M.9, D-2-1-2 x Super Strain B and HE-19-1-1 x Super Strain B are considered the best specific combinations since showed desirable significant SCA effect values for most studied traits.
\end{abstract}

Keywords: Solanum lycopersicum L, gene effects, GCA, heritability.

\section{INTRODUCTION}

Tomato (Solanum lycopersicum L.) is one of the most important vegetable crops, with a value of over $\$ 80.89$ billion globally (FAOSTAT, 2011). Its production has increased tremendously due to its multifarious uses (Tiwari and Choudhury 1986). There is demand for developing high yielding cultivars and or hybrids worldwide. Hybrids are usually known to be characterized by good quality characters and high yield. Therefore, tomato hybrids were, extensively, used in commercial production (Solieman et al., 2013 and Shalaby 2013). Combining ability analysis is an important technique to understand the genetic potential of parents and their hybrids. It also provides the information on gene effects to help breeders in formulating an effective breeding strategy. Griffing (1956) stated that general combining 
ability (GCA) is dued to additive type of gene action, while specific combining ability (SCA) is dued to non-additive gene action. The present investigation was undertaken to determine the best parental combinations having high yield and quality for Local cultivation.

\section{MATERIALS AND METHODS}

The experiments were carried out at Sidi Salim distract, Kafr El Sheikh Governorate during the period from 2010 to 2013. From previously done work, fifteen lines viz., M.4.2.1, M.5.3.1, M.12.2.1, D.2.1.2, D.4.3.1, D.7.3.1, HE.4.2.1, HE.6.5.1, HE.13.1.1, HE.13.2.1, HE.14.1.1, HE.15.2.1, HE.15.4.1, HE.19.1.1, and HE.19.3.1 were selected visually from three $F_{2}$ populations according to their good performance levels of vegetative and fruit quality traits, to be continued in the breeding program as lines. Before hybridization process the chosen fifteen lines were self-pollinated for three generations from 2010 to 2012 to achieve high degree of homozygosity and uniformity. These lines were crossed with three commercial cultivars viz., Super strain B, Super Bader and F.M.9 as testers in the summer season of 2013. Line $x$ tester mating design (Kempthorne, 1957) was carried out to produce $45 F_{1}$ hybrids. On $10^{\text {th }}$ July 2013 , seeds of the 15 lines, 3 testers and $45 F_{1}$ hybrids were sown in an evaluation trial in a randomized complete block design with three replications. Each replicate consisted of 63 plots (15 lines, 3 testers, 45 $F_{1}$ hybrids) each plot was one ridge of 6 meters length, 1.25 meters width and $7.5 \mathrm{~m}^{2}$. Also the distance between plants was $50 \mathrm{~cm}$ and each plot contained 12 plants. Cultural practices, such as fertilization, irrigation, and weed diseases and insects control were performed whenever they were thought necessary, as recommended for commercial tomato production in Kafr El Sheikh Governorate.

Data for plant height $(\mathrm{cm})$, number of branches per plant were recorded after 60 days from transplanting. Number of nodes to first fruit cluster, total yield per plant (number and weight $\mathrm{kg}$ ), average fruit weight $(\mathrm{g})$, total soluble solids (T.S.S.\%) and number of locules per fruit, ascorbic acid content $(\mathrm{mg} / 100 \mathrm{~g})$ and titratable acidity percentage, were recorded. The analysis of variance, to estimate components of variance, coefficient of variability, genotypic and phenotypic coefficient of variation, combining ability, component of genetic variance (additive variance $\sigma^{2} \mathrm{~A}$, dominance variance $\left.\sigma^{2} D\right)$ were carried out as suggested by Kempthorne (1957), Singh and chaudhary (1995). Degree of dominance was made according to Patel et al. (2004).

\section{RESULTS AND DISCUSSION}

\section{Analysis of variance}

The analysis of variance for combining ability revealed significant differences among parents, crosses, lines, testers and their interaction for all studied characters (Tables 1 and 2), indicating a wide range of variability among the genotypes. The lines expressed greater magnitude of mean squares than testers for all studied traits with exception of number of nodes to 
first cluster, average fruit weight and ascorbic acid content. Furthermore, mean square values of both lines and testers were higher in magnitude than those of lines $x$ testers for all studied traits, indicating lines and testers were highly divergent which justifies the choice of these materials. High significant parents vs crosses (Heterosis) mean squares were observed for all the studied traits except for number of fruits per plant, ascorbic acid content and titratable acidity indicated the expression of heterotic effects. These results are in agreement that with those of Sharma et al. (1999) for total yield, average fruit weight and TSS\% and Amin et al. (2001), for plant height and number of branches. Similarly, Garg et al. (2008) and Mondal et al. (2009) found significant mean square values parents vs hybrids for indicating considerable amount of average heterosis reflected in the hybrids for the same studied traits.

Table (1): Analysis of variance and mean squares, coefficient of variance (C.V. \%) components of variance, heritability and components of genetic variance for some tomato characteristics.

\begin{tabular}{|c|c|c|c|c|c|c|}
\hline \multirow[b]{2}{*}{ S.O.V. } & \multirow[b]{2}{*}{$\begin{array}{l}\text { Plant } \\
\text { height }\end{array}$} & \multirow{2}{*}{$\begin{array}{c}\text { No. of } \\
\text { branches }\end{array}$} & \multirow{2}{*}{$\begin{array}{c}\text { No. of } \\
\text { nodes to } \\
\text { first } \\
\text { cluster }\end{array}$} & \multicolumn{2}{|c|}{ Total yield/plant } & \multirow[b]{2}{*}{$\begin{array}{c}\text { Average } \\
\text { fruit } \\
\text { weight }\end{array}$} \\
\hline & & & & Number & Weight & \\
\hline Replications & $22.13^{*}$ & 1.33 & 0.26 & $210.10^{* *}$ & $3.10^{\star *}$ & 15.89 \\
\hline Treatments & $239.31^{\star *}$ & $10.06^{\star *}$ & $12.92^{\star *}$ & $739.38^{\star \star}$ & $16.81^{\star \star}$ & $1,726.53^{\star *}$ \\
\hline Parents & $273.36^{\star *}$ & $10.65^{\star *}$ & $27.18^{* *}$ & $1,026.50^{* *}$ & $24.87^{* \star}$ & $2,182.62^{* *}$ \\
\hline Crosses & $230.92^{\star \star}$ & $9.71^{\star *}$ & $6.94^{\star \star}$ & $645.25^{\star \star}$ & $14.02^{\star \star}$ & $1,533.64^{\star *}$ \\
\hline Par. Vs crosses & $29.44^{*}$ & $15.20^{* *}$ & $33.92^{* *}$ & 0.04 & $2.89^{* *}$ & $2,460.35^{\star *}$ \\
\hline Lines & $509.52^{\star \star}$ & $14.68^{\star \star}$ & $4.79^{\star \star}$ & $1,456.31^{\text {** }}$ & $30.36^{\star \star}$ & $2,297.56^{\star \star}$ \\
\hline Testers & $106.32^{\star \star}$ & 0.81 & $12.37^{\star \star}$ & 33.57 & $9.92^{\star \star}$ & $2,670.03^{\star *}$ \\
\hline Lines $x$ testers & $100.52^{\star \star}$ & $7.86^{* *}$ & $7.62^{\star \star}$ & $283.42^{\star *}$ & $6.14^{\star \star}$ & $1,070.50^{\star *}$ \\
\hline Residual & 6.70 & 0.89 & 0.56 & 15.24 & 0.28 & 39.67 \\
\hline Mean & 45.17 & 9.07 & 9.46 & 45.55 & 5.43 & 117.25 \\
\hline Rang & $\begin{array}{c}30.60- \\
63.07\end{array}$ & $\begin{array}{l}4.37- \\
13.30\end{array}$ & $\begin{array}{l}5.93- \\
19.30\end{array}$ & $\begin{array}{c}10.53- \\
86.00\end{array}$ & $\begin{array}{l}0.82- \\
12.27\end{array}$ & $\begin{array}{l}70.10- \\
180.60\end{array}$ \\
\hline C. V.\% & 5.570 & 10.790 & 7.810 & 8.670 & 9.710 & 5.390 \\
\hline$\sigma^{2} \mathrm{~g}$ & 81.89 & 3.21 & 4.52 & 278.11 & 6.08 & 572.04 \\
\hline$\sigma^{2} p$ & 88.23 & 4.17 & 5.07 & 293.77 & 6.36 & 612.03 \\
\hline $\mathrm{h}^{2} \mathrm{bs}$ & 92.81 & 76.96 & 89.15 & 94.67 & 95.60 & 93.47 \\
\hline G.C.V. \% & 20.03 & 19.75 & 22.48 & 36.61 & 45.38 & 20.40 \\
\hline P.C.V. \% & 20.79 & 22.52 & 23.81 & 37.62 & 46.42 & 21.10 \\
\hline G.C.V. / P.C.V. & 0.96 & 0.88 & 0.94 & 0.97 & 0.98 & 0.97 \\
\hline$\sigma_{L}^{2}$ & 45.445 & 0.757 & -0.315 & 130.321 & 2.691 & 136.34 \\
\hline$\sigma_{T}^{2}$ & -0.681 & -0.185 & -0.008 & -5.823 & -0.012 & 15.745 \\
\hline$\sigma^{2}$ average (GCA) & 1.805 & 0.025 & 0.005 & 5.025 & 0.105 & 6.56 \\
\hline$\sigma^{2} \operatorname{LxT}(\mathrm{SCA})$ & 31.27 & 2.32 & 2.35 & 89.39 & 1.95 & 343.61 \\
\hline$\sigma^{2} \mathrm{GCA} / \mathrm{SCA}$ & 0.058 & 0.011 & 0.002 & 0.056 & 0.054 & 0.019 \\
\hline$\sigma^{2}$ Addative $(A)$ & 3.61 & 0.05 & 0.01 & 10.05 & 0.21 & 13.12 \\
\hline$\sigma^{2}$ Dominance(D) & 31.27 & 2.32 & 2.35 & 89.39 & 1.95 & 343.61 \\
\hline$\sigma^{2} A / \sigma^{2} D$ & 0.115 & 0.022 & 0.004 & 0.112 & 0.108 & 0.038 \\
\hline degree of dominance & 2.94 & 6.81 & 15.33 & 2.98 & 3.05 & 5.12 \\
\hline pro. Cont L\% & 70.21 & 48.1 & 21.96 & 71.81 & 68.91 & 47.67 \\
\hline pro. Cont T \% & 2.09 & 0.38 & 8.11 & 0.24 & 3.22 & 7.91 \\
\hline
\end{tabular}




\section{Components of variance}

Mean range, coefficient of variability (C.V. \%) genotypic and phenotypic variance $\left(\sigma^{2} g\right.$ and $\left.\sigma^{2} p\right)$, heritability in broad sense $\left(h^{2}{ }_{b s}\right)$, genotypic and phenotypic coefficient of variance (G.C.V. and P.C.V. \%) and the ratio of G.C.V. / P.C.V. are shown in Tables 1 and 2. Obtained data showed that, the variance varied from trait to another, since the coefficient of variation (C.V. \%) ranged from 4.70 to $15.14 \%$. The highest C.V. \% value $(15.14 \%)$ was recorded in titratable acidity, followed by (10.79 and 9.71) for number of branches per plant and total yield per plant, respectively. So that these three characters had the highest variation among the studied genotypes. On the contrary, the lowest variation (4.70) was observed for total soluble solids (T.S.S \%).

Table (2): Analysis of variance and mean squares, coefficient of variance (C.V. $\%$ components of variance, heritability and components of genetic variance for some tomato characteristics.

\begin{tabular}{|c|c|c|c|c|}
\hline S.O.V. & $\begin{array}{c}\text { Total soluble } \\
\text { solids (T.S.S. \%) }\end{array}$ & $\begin{array}{l}\text { Number of } \\
\text { locules / fruit }\end{array}$ & $\begin{array}{c}\text { Ascorbic acid } \\
\text { (V.C) } \\
\text { (mg/100g) }\end{array}$ & $\begin{array}{c}\text { Titratable } \\
\text { acidity }\end{array}$ \\
\hline Replications & 0.00 & $0.32^{\star \star}$ & 4.95 & 0.01 \\
\hline Treatments & $0.53^{\star *}$ & $2.29^{\star \star}$ & $47.56^{\star \star}$ & $0.02^{\star \star}$ \\
\hline Parents & $0.31^{* *}$ & $3.03^{\star *}$ & $43.18^{* *}$ & $0.02^{* *}$ \\
\hline Crosses & $0.61^{\star *}$ & $1.80^{\star \star}$ & $50.24^{* *}$ & $0.02^{* *}$ \\
\hline Par. Vs crosses & $0.63^{\star *}$ & $11.61^{* *}$ & 4.10 & 0.00 \\
\hline Lines & $1.25^{\star \star}$ & $3.39^{* *}$ & $36.59^{* *}$ & $0.02^{*}$ \\
\hline Testers & $0.23^{\star *}$ & $1.89^{* \star}$ & $81.24^{\star \star}$ & 0.02 \\
\hline Lines $x$ testers & $0.32^{\star *}$ & $1.00^{\star *}$ & $54.84^{\star \star}$ & $0.02^{*}$ \\
\hline Residual & 0.04 & 0.06 & 8.44 & 0.01 \\
\hline Mean & 4.19 & 4.21 & 28.52 & 0.64 \\
\hline Rang & $3.00-6.00$ & $2.03-5.93$ & $20.79-36.13$ & $0.51-0.80$ \\
\hline C. V.\% & 4.700 & 5.950 & 7.280 & 15.140 \\
\hline$\sigma^{2} g$ & 0.21 & 0.72 & 13.37 & 0.003 \\
\hline$\sigma^{2} p$ & 0.25 & 0.78 & 17.68 & 0.013 \\
\hline $\mathrm{h}^{2}$ bs & 84.38 & 92.34 & 75.63 & 23.08 \\
\hline G.C.V. \% & 10.96 & 20.22 & 12.82 & 8.51 \\
\hline P.C.V. \% & 11.93 & 21.04 & 14.74 & 17.70 \\
\hline G.C.V. / P.C.V. & 0.92 & 0.96 & 0.87 & 0.48 \\
\hline$\sigma^{2} L$ & 0.103 & 0.265 & -2.028 & 0.001 \\
\hline$\sigma_{T}^{2}$ & -0.026 & -0.016 & -0.037 & -0.022 \\
\hline$\sigma^{2}$ average (GCA) & 0.003 & 0.01 & -0.049 & -0.001 \\
\hline$\sigma^{2}$ LXT (SCA) & 0.094 & 0.31 & 15.46 & 0.003 \\
\hline$\sigma^{2} G C A / S C A$ & 0.032 & 0.032 & -0.003 & -0.333 \\
\hline$\sigma^{2}$ Addative (A) & 0.006 & 0.02 & -0.098 & -0.002 \\
\hline$\sigma^{2}$ Dominance $(D)$ & 0.094 & 0.31 & 15.46 & 0.003 \\
\hline$\sigma^{2} A / \sigma^{2} D$ & 0.064 & 0.065 & -0.006 & -0.667 \\
\hline degree of dominance & 3.96 & 3.94 & 0.019 & 14.91 \\
\hline pro. Cont L \% & 64.87 & 59.85 & 23.18 & 35.57 \\
\hline pro. Cont T \% & 1.73 & 4.77 & 7.35 & 4.38 \\
\hline pro. Cont LxT\% & 33.4 & 35.37 & 69.47 & 60.05 \\
\hline
\end{tabular}

Regarding the genotypic and phenotypic variance $\left(\sigma^{2} g\right.$ and $\left.\sigma^{2} p\right)$, estimated $\sigma^{2} g$ vs. $\sigma^{2} p$ for the studied traits are presented in Tables 1 and 2 . 
The values were 81.89 vs. 88.23 for plant height; 3.21 vs 4.17 for number of branches; 4.52 vs. 5.07 for number of nodes to first fruit cluster; 278.11 vs 293.77 for number of fruits per plant; 6.08 vs. 6.36 for total yield per plant; 572.04 vs. 612.03 for average fruit weight; 0.21 vs 0.25 for TSS\%; 0.72 vs 0.78 for number of locules per fruit; 13.37 vs 17.68 for ascorbic acid content and 0.003 vs 0.013 for titratable acidity percentage respectively. In this respect, all the studied traits showed narrow of difference between phenotypic and genotypic variance, which leaded to a close correspondence varies between genotypic and phenotypic coefficient of variations (G.C.V. and P.C.V. \%). The estimated G.C.V. vs P.C.V. \% were: 20.03 vs 20.79 for plant height; 19.75 vs 22.52 for number of branches; 22.48 vs 23.81 for number of nodes to first cluster; 36.61 vs 37.62 for number of fruits per plant, 45.38 vs 46.42 for total yield per plant; 20.40 vs 21.10 for average fruit weight; 10.96 vs 11.93 for TSS\%; 20.22 vs 21.04 for number of locules per fruit; 12.82 vs 14.74 for ascorbic acid content and 8.51 vs 17.70 for titratable acidity respectively. Consquently, the G.C.V. / P.C.V. ratio for the studied traits showed high values which ranged from 0.87 for ascorbic acid to 0.98 for total yield / plant except for titratable acidity where the ratio was 0.48 . Estimates of broad sense heritability $\left(h^{2} b s\right)$ were found to be high for most of the studied traits except for titratable acidity percentage that was low. The ratio ranged from $23.08 \%$ for titratable acidity to $95.60 \%$ for total yield per plant.

Generally, the difference between the genotypic $\left(\sigma^{2} g\right)$ and phenotypic $\left(\sigma^{2} p\right)$ variances indicated the contribution of environmental variance effects. The smaller the value of difference between $\sigma^{2} p$ and $\sigma^{2} g$, the less will be the environmental effect on the character. Selection based on the phenotypic values will be effective only when the phenotypic values represented truly the genotypic values. In this respect, all the studied characters have closer values of $\sigma^{2} g$ and $\sigma^{2} p$ as well as G.C.V. \% and P.C.V. \%, respectively which was confirmed by the estimated G.C.V. / P.C.V. ratios that ranged from 0.48 to 0.98 , and the broad sense heritability ( $h^{2}$ bs) which ranged from $75.63-$ $95.60 \%$, excluding that of titratable acidity that was 23.08 . This suggests less effect of environmental on these traits and the large portion of $\sigma^{2} p$ was due to the $\sigma^{2} g$. Hence, selection for these traits could be effective to improve tomato plants. These results are confirmed by earlier findings of Metwally et al. (1996), for early and total yield and average fruit weight; Joshi and Singh (2003) and Asati et al. (2008) for plant height and number of branches, total yield and average fruit weight.

\section{Components of genetic variance}

By line $\mathrm{x}$ tester mating design, the genetic variation could be partitioned into components of genetic variance in terms of additive and nonadditive genetic variance. Both lines variance $\left(\sigma^{2}{ }_{L}\right)$ and testers variance $\left(\sigma_{T}^{2}\right)$ estimate the general combining ability variance $\left(\sigma^{2} G C A\right)$ which considered as an indicator of additive $\left(\sigma^{2} A\right)$ and additive $x$ additive $\left(\sigma^{2} A A+\sigma^{2} A A A+\ldots \ldots.\right)$ portions of genetic variance. While, the line $x$ tester variance $\left(\sigma_{L x T}^{2}\right)$ which is estimate the specific combining ability variance $\left(\sigma^{2} S C A\right)$ reflected the nonadditive genetic portions including dominance $\left(\sigma^{2} D\right)$ and $\left(\sigma^{2} D D+\ldots ..\right)$, in 
addition to the maternal effect. However, Kallo (1988) mentioned that additive $\left(\sigma^{2} A\right)$ and dominance $\left(\sigma^{2} D\right)$ were the most important portions. The variance of lines $\left(\sigma^{2}\right)$, testers $\left(\sigma_{T}^{2}\right)$, average lines and testers $\left(\sigma^{2} G C A\right.$ or $\left.\sigma^{2} A\right)$, line $x$ tester interaction $\left(\sigma^{2} S C A\right.$ or $\left.\sigma^{2} D\right)$, degree of dominance, and the proportional contribution of lines, testers and $L \times T$ were obtained for all studied traits as shown in Tables 1 and 2. The results mentioned that the magnitude of $\left(\sigma^{2} L\right)$ was always were larger than the corresponding $\left(\sigma^{2}{ }_{T}\right)$ for all the studied traits, except of number of nodes to first fruit cluster and ascorbic acid content, indicating the importance of right choice of the parents.

As mentioned before, the analysis of variance for combining ability revealed highly significant mean square values for lines, testers and line $x$ tester interactions for all the studied traits. Then, the variance values for lines $\left(\sigma^{2} \mathrm{~L}\right)$, testers $\left(\sigma^{2} \mathrm{~T}\right)$ average lines by testers (general combining ability; i.e., $\sigma^{2} G C A$ ) and $\sigma^{2}{ }_{L x T}$ (specific combining ability; i.e., $\sigma^{2} S C A$ ) are considered highly significant, suggesting the importance of both additive $\left(\sigma^{2} A\right)$ and nonadditive $\left(\sigma^{2} D\right)$ gene action in the inheritance of all studied traits. This information pointed out that the characters could be improved through selecting promising lines from superior hybrids. However, the ratio of $\sigma^{2} \mathrm{GCA} /$ $\sigma^{2} S C A$ was less than unit $(<1)$ for all the studied traits, which revealed the preponderance of non-additive variance in the inheritance of these traits. The prevalence of the non-additive variance was further confirmed by calculated $\sigma^{2} A / \sigma^{2} D$ ratios which also was less than one for all the studied traits, suggesting that heterosis breeding as another approach is effective for improvement these traits. The estimated average degree of dominance was also more than one $(>1)$, indicating over-dominance for all the studied traits with the exception of fruit length and titratable acidity which showed complete dominance. Lastly, estimated proportional contribution values showed that, the lines recorded greater proportion than both testers and $L \times T$ interaction for all the studied traits, except for number of nodes to first fruit cluster, ascorbic acid content and titratable acidity percentage.

Regarding number of nodes to first cluster, the testers used reflected the highest value (69.93). Based on contribution of lines, testers and $L \times T$ interaction, it was evident that the variability among the crosses was mainly due to the contribution of lines for majority of the studied traits, which also justifies of choice of the parents. Several previous studies in tomato mentioned the significance of additive and non-additive genetic variances with predominance of non-additive gene action in the inheritance of studied same traits; e. g. Metwallly et al. (1996), Amin et al. (2001), Bhatt et al. (2001), Hanan et al. (2007), Garg et al. (2008), Saeed et al. (2008) and Mondal et al. (2009).

\section{General and specific combining ability effects}

The estimates of GCA of the parents for different characters are presented in Table (3). The good combiner parents for the studied traits were HE.13.2.1 and M.5.3.1 for plant height; HE.13.1.1 and HE.13.2.1 for number of branches, D.4.3.1 for number of nodes to first cluster, D.7.3.1, D.7.3.1 and HE.19.1.1 for number of fruit per plant, HE.6.5.1 and HE.19.1.1 for total yield per plant, HE.15.4.1, HE.13.2.1and HE.6.5.1 for average fruit weight, 
HE.13.2.1 and D.2.1.2 for total soluble solids (TSS\%), D.2.1.2 and HE.13.1.1 for number of locules per fruit and HE.19.1.1 for ascorbic acid content.

Table (3): General combining ability (GCA) effects of parental lines for some plant and fruit characteristics.

\begin{tabular}{|c|c|c|c|c|c|c|c|c|c|c|}
\hline \multirow[b]{2}{*}{ Lines } & \multirow[b]{2}{*}{$\begin{array}{l}\text { Plant } \\
\text { height }\end{array}$} & \multirow[b]{2}{*}{$\begin{array}{c}\text { No. of } \\
\text { branches }\end{array}$} & \multirow{2}{*}{$\begin{array}{l}\text { No. of } \\
\text { nodes to } \\
\text { first } \\
\text { cluster }\end{array}$} & \multicolumn{2}{|c|}{\begin{tabular}{|l|} 
Total yield/plant \\
\end{tabular}} & \multirow[b]{2}{*}{$\begin{array}{c}\text { Average } \\
\text { fruit weight }\end{array}$} & \multirow{2}{*}{$\begin{array}{c}\text { Total } \\
\text { soluble } \\
\text { solids } \\
\text { (T.S.S.\%) }\end{array}$} & \multirow[b]{2}{*}{$\begin{array}{c}\text { Number } \\
\text { of } \\
\text { locules } \\
\text { / fruit }\end{array}$} & \multirow[b]{2}{*}{$\begin{array}{c}\text { Ascorbic } \\
\text { acid(V.C) } \\
\text { (mg/100g) }\end{array}$} & \multirow[b]{2}{*}{$\begin{array}{c}\text { Titratable } \\
\text { acidity }\end{array}$} \\
\hline & & & & Number & Weight & & & & & \\
\hline M.4.2.1 & $-5.56^{\star \star}$ & $-1.58^{\star \star}$ & 0.18 & $-7.94^{\star *}$ & $-1.93^{\star \star}$ & $-23.27^{\star *}$ & $-0.53^{\star *}$ & $-1.47^{\star *}$ & -1.26 & -0.02 \\
\hline M.5.3.1 & $11.89^{\star \star}$ & 0.59 & $1.93^{\star \star}$ & -0.65 & $-0.59^{*}$ & $-9.77^{\star \star}$ & $-0.93^{\star \star}$ & -0.08 & 0.53 & $-0.10^{*}$ \\
\hline M.12.2.1 & -1.19 & $-1.41^{* *}$ & -0.58 & $-12.94^{\star \star}$ & $-2.27^{\star *}$ & $-21.52^{\star *}$ & $-0.19^{*}$ & $0.58^{* *}$ & -1.02 & -0.02 \\
\hline D.2.1.2 & $-8.08^{\star \star}$ & -0.88 & -0.21 & $-9.52^{* *}$ & $-2.28^{\star \star}$ & $-20.12^{\star \star}$ & $0.45^{\star \star}$ & $0.81^{* \star}$ & -0.13 & 0.02 \\
\hline D.4.3.1 & $-8.82^{\star \star}$ & $-2.24^{\star *}$ & $-1.15^{\star \star}$ & $-16.63^{\star *}$ & $-2.01^{* *}$ & -3.21 & -0.11 & $-0.59^{* *}$ & -0.75 & 0.04 \\
\hline D.7.3.1 & $7.11^{\star \star}$ & $1.08^{*}$ & -0.03 & $25.33^{\star \star}$ & $3.07^{\star *}$ & -0.42 & $0.29^{\star \star}$ & $-0.38^{\star \star}$ & -0.47 & -0.06 \\
\hline HE.4.2.1 & $-3.86^{\star \star}$ & 0.33 & $0.89^{*}$ & $-9.80^{* *}$ & -0.36 & $24.49^{\star *}$ & $0.25^{*}$ & $0.72^{\star \star}$ & -1.10 & 0.02 \\
\hline HE.6.5.1 & $9.12^{* \star}$ & 0.53 & -0.72 & $8.83^{\star *}$ & $2.08^{* *}$ & $18.44^{\star *}$ & -0.08 & $0.32^{* \star}$ & 1.83 & 0.02 \\
\hline HE.13.1.1 & 1.95 & $2.23^{\star *}$ & 0.01 & $8.51^{\star *}$ & $0.83^{\star *}$ & -1.86 & $0.38^{* *}$ & $0.73^{\star *}$ & -4.59 & -0.03 \\
\hline HE.13.2.1 & $14.94^{\star \star}$ & $2.18^{\star \star}$ & -0.47 & $9.45^{\star \star}$ & $1.94^{* *}$ & $14.14^{\star *}$ & $0.47^{* *}$ & $0.23^{*}$ & 1.57 & 0.00 \\
\hline HE.14.4.1 & 0.04 & -0.51 & 0.22 & -3.69 & -0.44 & -0.27 & -0.11 & 0.11 & 0.82 & 0.05 \\
\hline HE.15.2.1 & -2.38 & -0.31 & 0.19 & $-14.30^{\star *}$ & $-1.96^{* \star}$ & $-8.19^{*}$ & -0.04 & $-0.37^{\star *}$ & 2.00 & 0.00 \\
\hline HE.15.4.1 & -1.84 & 0.42 & 0.25 & \begin{tabular}{|l|}
-0.87 \\
\end{tabular} & $1.12^{\star \star}$ & $28.12^{\star \star}$ & 0.07 & 0.04 & -0.93 & -0.04 \\
\hline HE.19.1.1 & $-7.76^{\star \star}$ & 0.16 & 0.04 & $21.55^{\star \star}$ & $2.17^{* \star}$ & -3.37 & 0.01 & $-0.49^{\star \star}$ & $4.35^{\star \star}$ & 0.07 \\
\hline HE.19.3.1 & $-5.55^{\star *}$ & -0.59 & -0.56 & 2.68 & $0.63^{*}$ & $6.81^{*}$ & 0.05 & -0.12 & -0.86 & 0.07 \\
\hline LSD0.05 & 2.61 & 0.95 & 0.74 & 3.93 & 0.53 & 6.33 & 0.19 & 0.23 & 2.91 & 0.09 \\
\hline LSD0.01 & 3.63 & 1.32 & 1.04 & 5.47 & 0.74 & 8.79 & 0.27 & 0.32 & 4.03 & 0.13 \\
\hline \multicolumn{11}{|l|}{ TESTERS } \\
\hline $\begin{array}{l}\text { Super } \\
\text { Strain B } \\
\end{array}$ & -1.33 & 0.01 & -0.16 & -0.90 & $-0.51^{*}$ & $-8.05^{\star}$ & -0.07 & -0.07 & -0.55 & -0.02 \\
\hline $\begin{array}{l}\text { Super } \\
\text { Bader } \\
\end{array}$ & -0.36 & -0.13 & -0.43 & 0.82 & 0.09 & 0.75 & 0.08 & $0.23^{*}$ & 1.53 & 0.01 \\
\hline F.M.9 & 1.68 & 0.14 & 0.59 & 0.08 & 0.42 & $7.30^{*}$ & -0.01 & -0.16 & -0.98 & 0.01 \\
\hline LSD0.05 & 2.32 & 0.85 & 0.67 & 3.52 & 0.47 & 5.67 & 0.17 & 0.22 & 2.62 & 0.08 \\
\hline LSD0.01 & 5.35 & 1.97 & 1.55 & 8.13 & 1.09 & 13.09 & 0.4 & 0.51 & 6.05 & 0.19 \\
\hline
\end{tabular}

${ }^{*},{ }^{\star \star}=$ significant at 0.05 and 0.01 probability levels, respectively.

Since they showed significant positive GCA values except for the number of nodes to first cluster. Parent D.4.3.1 showed highly significant negative value of GCA effect. High significant positive GCA values were obtained by some lines; e. g. for the various traits were: HE.13.2.1 for plant height and number of branches (14.94 and 2.18, respectively); D.4.3.1 for number of nodes to first cluster (-1.15); D.7.3.1 for total yield per plant and number of fruits per plant (3.07 and 25.33, respectively) and HE.15.4.1 for average fruit weight (28.12), and they are considered the best combiner parent for these traits in the present study. Generally, the lines D.7.3.1 and HE.13.2.1 were found to be the most desirable general combiner. It possesses dominance for four traits, followed by the lines HE.13.2.1 and HE.19.1.1 which were good general combiners for three and two traits, respectively. As previously known, the general combining ability (GCA) effects is considered as an indicator of additive $\left(\sigma^{2} A\right)$ and additive $x$ additive $\left(\sigma^{2} A A+\sigma^{2} A A A+\ldots\right)$ portions of genetic variance and represent the fixable components of genetic variance. So, these characters could be improved using these lines in hybrid breeding programmes for the accumulation of favorable genes. In this respect, Garg et al. (2008), Mondal et al. (2009) and Kansouh and Zakher (2011) mentioned that, the GCA effects are mainly 
attributed to additive and additive $\mathrm{x}$ additive interactions, which are fixable and parent lines/cultivars with high GCA may be recommended for utilization in genetic improvement of tomato through varietal breeding.

JTable (4): Specific combining ability (SCA) effects of the cross combinations for some plant and fruit characteristics.

\begin{tabular}{|c|c|c|c|c|c|}
\hline \multirow{2}{*}{ Crosses } & \multirow{2}{*}{ Plant height } & \multirow{2}{*}{ No. of branches } & \multirow{2}{*}{$\begin{array}{l}\text { No. of nodes } \\
\text { to first cluster }\end{array}$} & \multicolumn{2}{|c|}{ Total yield/plant } \\
\hline & & & & Number & Weight \\
\hline $1 \times 16$ & 3.77 & 0.54 & -0.21 & -3.57 & 0.56 \\
\hline $1 \times 17$ & -3.86 & -0.27 & -0.17 & -5.32 & -0.60 \\
\hline $1 \times 18$ & 0.09 & -0.27 & 0.38 & $8.89^{* *}$ & 0.04 \\
\hline $2 \times 16$ & -0.88 & -0.10 & 0.61 & 3.21 & -0.50 \\
\hline $2 \times 17$ & $5.01^{*}$ & $2.33^{\star *}$ & -0.56 & -1.28 & -0.40 \\
\hline $2 \times 18$ & -4.13 & $-2.24^{\star *}$ & -0.04 & -1.93 & $0.90^{*}$ \\
\hline $3 \times 16$ & $6.96^{\star *}$ & -0.63 & 0.48 & 4.63 & $1.11^{*}$ \\
\hline $3 \times 17$ & $-6.58^{\star *}$ & 0.50 & -0.09 & -0.22 & -0.12 \\
\hline $3 \times 18$ & -0.38 & 0.13 & -0.40 & -4.41 & $-0.99^{*}$ \\
\hline $4 \times 16$ & $9.08^{\star *}$ & $2.07^{\star \star}$ & $1.98^{\star *}$ & $23.81^{\star \star}$ & $1.42^{\star \star}$ \\
\hline $4 \times 17$ & -4.02 & 0.17 & -0.89 & $-7.71^{*}$ & -0.31 \\
\hline $4 \times 18$ & $-5.06^{*}$ & $-2.24^{* *}$ & -1.10 & $-16.10^{\star *}$ & $-1.11^{*}$ \\
\hline $5 \times 16$ & -4.64 & $-2.30^{\star \star}$ & -0.22 & $-6.75^{\star}$ & $-0.96^{*}$ \\
\hline $5 \times 17$ & -3.04 & -1.07 & 0.71 & $-10.73^{\star \star}$ & $-1.25^{\star \star}$ \\
\hline $5 \times 18$ & $7.68^{\star *}$ & $3.36^{\star \star}$ & -0.50 & $17.48^{\star \star}$ & $2.21^{\star *}$ \\
\hline $6 \times 16$ & 1.99 & -1.39 & 0.24 & $-8.50^{*}$ & $-1.80^{\star *}$ \\
\hline $6 \times 17$ & $-7.98^{* *}$ & 0.64 & -1.16 & 0.21 & 0.10 \\
\hline $6 \times 18$ & $5.98^{\star \star}$ & 0.74 & 0.93 & $8.29^{*}$ & $1.70^{\star \star}$ \\
\hline $7 \times 16$ & $6.54^{\star *}$ & -0.51 & -0.78 & 5.39 & $1.03^{*}$ \\
\hline $7 \times 17$ & -2.70 & 1.39 & -0.55 & -0.23 & 0.17 \\
\hline $7 \times 18$ & -3.84 & -0.88 & $1.34^{*}$ & -5.15 & $-1.20^{* *}$ \\
\hline $8 \times 16$ & $-4.55^{\star}$ & $2.06^{*}$ & 0.99 & -1.20 & -0.35 \\
\hline $8 \times 17$ & $7.78^{\star *}$ & 0.02 & -0.61 & $-6.62^{*}$ & $-1.08^{*}$ \\
\hline $8 \times 18$ & -3.23 & $-2.08^{* \star}$ & -0.39 & $7.82^{*}$ & $1.43^{\star \star}$ \\
\hline $9 \times 16$ & $-5.04^{*}$ & -0.18 & $-1.81^{\star \star}$ & -3.32 & -0.46 \\
\hline $9 \times 17$ & $4.66^{*}$ & $-1.84^{*}$ & $3.09^{\star *}$ & 4.32 & -0.72 \\
\hline $9 \times 18$ & 0.38 & $2.02^{*}$ & $-1.29^{*}$ & -1.00 & $1.18^{\star *}$ \\
\hline $10 \times 16$ & -2.06 & 1.51 & $1.47^{*}$ & $-9.19^{\star *}$ & -0.84 \\
\hline $10 \times 17$ & 3.10 & -0.46 & -1.16 & $12.42^{\star \star}$ & $2.53^{\star \star}$ \\
\hline $10 \times 18$ & -1.04 & -1.06 & -0.31 & -3.23 & $-1.70^{\star *}$ \\
\hline $11 \times 16$ & -1.26 & -0.66 & -0.48 & -3.72 & $-1.16^{\star \star}$ \\
\hline $11 \times 17$ & -2.90 & -0.10 & -0.52 & $-6.71^{*}$ & -0.32 \\
\hline $11 \times 18$ & 4.16 & 0.76 & 1.00 & $10.43^{\star \star}$ & $1.48^{\star \star}$ \\
\hline $12 \times 16$ & -0.52 & -1.00 & -1.02 & 2.02 & $0.86^{*}$ \\
\hline $12 \times 17$ & $5.61^{*}$ & 0.13 & -1.15 & 1.70 & $0.87^{\star}$ \\
\hline $12 \times 18$ & $-5.10^{*}$ & 0.86 & $2.17^{\star \star}$ & -3.72 & $-1.73^{\star \star}$ \\
\hline $13 \times 16$ & $-6.48^{* *}$ & -0.36 & 0.05 & -2.70 & -0.48 \\
\hline $13 \times 17$ & -0.92 & -0.27 & -1.02 & $7.41^{*}$ & $1.36^{\star \star}$ \\
\hline $13 \times 18$ & $7.40^{\star \star}$ & 0.63 & 0.97 & -4.71 & $-0.87^{*}$ \\
\hline $14 \times 16$ & 1.34 & -0.46 & $-2.61^{* *}$ & 2.61 & $2.03^{* *}$ \\
\hline $14 \times 17$ & 2.80 & -0.83 & $3.96^{\star *}$ & $9.45^{\star *}$ & $-1.10^{*}$ \\
\hline $14 \times 18$ & -4.14 & 1.30 & $-1.35^{\star}$ & $-12.07^{\star \star}$ & $-0.93^{*}$ \\
\hline $15 \times 16$ & -4.24 & 1.41 & $1.29^{*}$ & -2.72 & -0.46 \\
\hline $15 \times 17$ & 3.02 & -0.36 & 0.13 & 3.32 & $0.88^{*}$ \\
\hline $15 \times 18$ & 1.22 & -1.06 & $-1.42^{*}$ & -0.60 & -0.42 \\
\hline L.S.D0.05 & 4.26 & 1.55 & 1.21 & 6.42 & 0.86 \\
\hline 0.01 & 5.69 & 2.07 & 1.62 & 8.58 & 1.16 \\
\hline
\end{tabular}

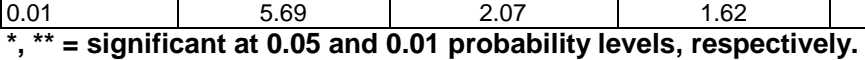

$1=$ M.4.2.1 2= M.5.3.1 3= M.12.2.1 4= D.2.1.2 5= D.4.3.1 6= D.7.3.1 7= HE.4.2.1 $8=$ HE.6.5.1 9= HE.13.1.1 10= HE.13.2.1 11= HE.14.4.1 12= HE.15.2.1 13= HE.15.4.1

14= HE.19.1.1 15= HE.19.3.1 16=Super Strain B 17=Super Bader 18= F.M.9 
Table (5): Specific combining ability (SCA) effects of the cross combinations for some plant and fruit characteristics.

\begin{tabular}{|c|c|c|c|c|c|}
\hline Crosses & $\begin{array}{c}\text { Average fruit } \\
\text { weight }\end{array}$ & $\begin{array}{c}\text { Total soluble } \\
\text { solids(T.S.S.\%) }\end{array}$ & $\begin{array}{c}\text { Number } \\
\text { of locules / } \\
\text { fruit }\end{array}$ & $\begin{array}{l}\text { Ascorbic } \\
\text { acid(V.C) } \\
\text { (mg/100g) }\end{array}$ & Titratable acidity \\
\hline $\mathrm{k} 16$ & $21.42^{\star *}$ & 0.13 & 0.14 & 2.27 & -0.02 \\
\hline $\mathrm{k} 17$ & -3.71 & $0.39^{*}$ & -0.17 & 0.76 & 0.12 \\
\hline $\mathrm{k} 18$ & $-17.70^{\star \star}$ & $-0.52^{\star \star}$ & 0.02 & -3.03 & -0.10 \\
\hline$k 16$ & $-19.22^{\star \star}$ & 0.13 & -0.25 & -0.35 & 0.03 \\
\hline $\mathrm{k} 17$ & -7.35 & 0.12 & -0.35 & -3.47 & 0.01 \\
\hline $\mathrm{k} 18$ & $26.57^{* *}$ & -0.25 & $0.60^{* *}$ & 3.81 & -0.05 \\
\hline $\mathrm{k16}$ & $14.06^{* *}$ & -0.07 & -0.28 & 3.51 & -0.03 \\
\hline k17 & -2.90 & 0.19 & $0.58^{* *}$ & $-5.85^{\star}$ & 0.01 \\
\hline $\mathrm{k} 18$ & $-11.16^{*}$ & -0.12 & -0.30 & 2.34 & 0.02 \\
\hline k16 & $-21.84^{\star \star}$ & $-0.51^{\star \star}$ & 0.30 & -3.79 & -0.05 \\
\hline K17 & 2.80 & $0.48^{\star \star}$ & $0.46^{*}$ & -2.95 & 0.07 \\
\hline $\mathrm{k} 18$ & $19.04^{* \star}$ & 0.03 & $-0.75^{\star \star}$ & $6.74^{\star \star}$ & -0.02 \\
\hline k16 & $-13.08^{*}$ & -0.02 & 0.06 & -1.20 & 0.04 \\
\hline 17 & 4.55 & -0.30 & $0.52^{\star}$ & 2.52 & -0.07 \\
\hline $\mathrm{k} 18$ & 8.53 & $0.32^{*}$ & $-0.59^{\star \star}$ & -1.32 & 0.03 \\
\hline $\mathrm{k16}$ & -9.57 & 0.31 & -0.08 & $6.27^{*}$ & 0.00 \\
\hline $\mathrm{k} 17$ & 1.70 & $-0.50^{\star \star}$ & -0.02 & -0.69 & 0.00 \\
\hline $\mathrm{k} 18$ & 7.88 & 0.19 & 0.10 & $-5.58^{*}$ & 0.00 \\
\hline k16 & 5.22 & $-0.51^{\star \star}$ & -0.21 & 2.99 & -0.10 \\
\hline $\mathrm{k} 17$ & 4.05 & $0.41^{\star}$ & 0.35 & 2.30 & 0.04 \\
\hline $\mathrm{k} 18$ & -9.27 & 0.10 & -0.13 & $-5.29^{*}$ & 0.06 \\
\hline k16 & -1.66 & 0.09 & $0.65^{\star \star}$ & 0.72 & -0.08 \\
\hline k17 & -3.79 & $-0.32^{*}$ & -0.29 & 0.24 & -0.02 \\
\hline $\mathrm{k} 18$ & 5.45 & 0.23 & -0.37 & -0.96 & 0.10 \\
\hline k16 & -1.29 & -0.18 & $-0.86^{\star \star}$ & -4.30 & 0.05 \\
\hline k17 & $-22.79^{\star \star}$ & $-0.32^{*}$ & -0.13 & $5.39^{*}$ & -0.05 \\
\hline k18 & $24.09^{* \star}$ & $0.50^{\star \star}$ & $0.99^{* \star}$ & -1.09 & 0.00 \\
\hline $0 \times 16$ & 9.64 & $0.33^{*}$ & 0.24 & 0.77 & -0.03 \\
\hline px17 & $12.87^{*}$ & -0.14 & -0.07 & 2.24 & 0.01 \\
\hline $5 \times 18$ & $-22.51^{\star \star}$ & -0.19 & -0.18 & -3.01 & 0.01 \\
\hline $1 \times 16$ & $-20.48^{\star \star}$ & 0.11 & -0.37 & 4.43 & 0.11 \\
\hline $1 \times 17$ & $14.29^{\star \star}$ & 0.10 & -0.31 & $-7.11^{\star \star}$ & -0.13 \\
\hline $1 \times 18$ & 6.20 & -0.21 & $0.68^{* *}$ & 2.68 & 0.03 \\
\hline $2 \times 16$ & $16.44^{\star \star}$ & 0.18 & 0.07 & -2.68 & 0.09 \\
\hline $2 \times 17$ & $20.11^{\star \star}$ & -0.03 & 0.03 & 1.51 & -0.03 \\
\hline $2 \times 18$ & $-36.55^{\star \star}$ & -0.14 & -0.11 & 1.17 & -0.06 \\
\hline $3 \times 16$ & -2.21 & 0.13 & 0.06 & -2.88 & -0.01 \\
\hline $3 \times 17$ & 3.40 & -0.08 & -0.21 & 2.83 & 0.06 \\
\hline $3 \times 18$ & -1.19 & -0.05 & 0.15 & 0.05 & -0.04 \\
\hline $4 \times 16$ & $25.15^{\star \star}$ & 0.00 & $1.26^{\star \star}$ & -0.64 & -0.11 \\
\hline $4 \times 17$ & $-31.21^{\star \star}$ & -0.01 & $-0.81^{\star \star}$ & 2.09 & 0.05 \\
\hline $4 \times 18$ & 6.07 & 0.01 & $-0.45^{\star}$ & -1.45 & 0.06 \\
\hline $5 \times 16$ & -2.56 & -0.11 & $-0.75^{\star \star}$ & $-5.12^{*}$ & 0.12 \\
\hline $5 \times 17$ & 8.01 & 0.01 & $0.41^{*}$ & 0.18 & -0.07 \\
\hline $5 \times 18$ & -5.45 & 0.10 & 0.33 & $4.94^{*}$ & -0.04 \\
\hline S.D0.05 & 10.38 & 0.32 & 0.4 & 4.78 & 0.17 \\
\hline 01 & 13.87 & 0.43 & 0.54 & 6.39 & 0.21 \\
\hline
\end{tabular}

${ }^{*},{ }^{* *}=$ significant at 0.05 and 0.01 probability levels, respectively.

$1=$ M.4.2.1 2= M.5.3.1 3= M.12.2.1 4= D.2.1.2 5= D.4.3.1 6= D.7.3.1 7= HE.4.2.1 $8=$ HE.6.5.1 9= HE.13.1.1 10= HE.13.2.1 11= HE.14.4.1 12=HE.15.2.1 13= HE.15.4.1 14= HE.19.1.1 15= HE.19.3.1 16=Super Strain B 17=Super Bader 18= F.M.9

Regarding specific combining ability (SCA) effects, data are presented in Tables (4 and 5) for the various studied traits. The highest significant SCA values were reflected by the cross D-2-1-2 x Super Strain B 
for plant height, number of branches per plant, number of fruits per plant and total yield $(9.08,2.07,23.81$ and 1.42, respectively); HE-19-1-1 x Super Strain B for number of nodes to first cluster, total yield, average fruit weight and number of locules per fruit $(-2.61,2.03,25.15$ and 1.26, respectively); HE-13-1-1 x F.M.9 for number of branches per plant, number of nodes to first cluster, total yield, average fruit weight, total soluble solids (TSS\%) and number of locules per fruit $(2.02,-1.29,1.18,24.09,0.50$ and 0.99 , respectively); D-4-3-1 x F.M.9 for plant height, number of branches, number of fruits per plant, total yield per plant and total soluble solids (TSS\%) (7.68, 3.36, 17.48, 2.21 and 0.32, respectively); M-5-3-1 x Super Bader for number of branches; M-5-3-1 x F.M.9 for average fruit weight; HE-13-2-1 x Super Bader for total yield per plant; D-2-1-2 x F.M.9 for ascorbic acid could be considered the best combinations for each trait. Over the whole, the cross combinations D-4-3-1 x F.M.9 and HE-19-1-1 x Super Strain B considered the best combinations, since they showed significant SCA values for three traits, followed by the combination D-2-1-2 x Super Strain B and HE-13-1-1 x F.M.9 which showed good SCA effects for two traits. These crosses involved the tester Super Strain B or F.M.9 as one parent.

Generally, since the SCA effects are considered an indicator for heterosis effects, where high amount of heterosis could be expected for some important traits in nine crosses out of the 45 crosses studied. Thus, nine crosses showed highly significant heterosis for fruit weight and nine showed highly significant total fruit yield / plant. Meanwhile, 9 crosse significant total number of fruits / plant and another six showed highly significant one. This findings agrees with the previously estimated degree of dominance value (Table 1) which was more than one for all traits studied (over dominance). So, the heterosis breeding method (hybrid development) could be used effectively for all traits studied. These results are in agreement with those of Bhatt et al. (2001), Hannan et al. (2007), and Kansouh and Zakher (2011).

\section{REFERENCES}

Amin, S. A.; M. M. Abd El-Maksoud and A. M. Abd El-Rahim (2001). Genetical studies on $F_{1}$ hybrids, $F_{2}$ generations and genetic parameters associated with it in tomato (Lycopersicon esculentum Mill). J. Agric. Sci. Mansoura Univ., 26(60): 3667-3675.

Asati, B. S; N. Rai and A. K. Singh (2008). Genetic parameters study for yield and quality traits in tomato. Asian J. Hort., vol. 3 (2):2 22-225.

Bhatt, R. P.; V. R. Biswas and N. Kumar (2001). Heterosis, combining ability and genetics for vitamin $C$, total soluble solids and yield in tomato (Lycopersicon esculentum Mill) at $17^{0}$ altitude. J. Agric. Sci., Cambridge, 137: 71-75.

FAO. (2011). Food and Agricultural Organization. Quarterly Bulletin Statistics, FAO, Rome.

Garg, N.; S.C. Devinder and S. D. Ajmer (2008). Genetic of yield, quality and shelf life characteristics in tomato under normal and late planting conditions. Euphytica, 159: 275-288. 
Griffing, B. (1956). Concept of general and specific combining ability in relation to diallel crossing system. Aust. J. Biol. Sci., 9:463-493.

Hannan, M. M.; M. K. Buswas; M. B. Ahmed; M. Hossain and R. Islam (2007). Combining ability analysis of yield and yield components in tomato (Lycopersicon esculentum Mill). Turkish of Botany, 31(6): 559563.

Joshi, A. and J. P. Singh (2003). Studieds of genetic variability in tomato. Prog. Hort., 35(2): 179-182.

Kallo (1988). Vegetable breeding. CRC Press Inc., 2000 corporate Bivd., N. W., Boca Raton, Florida, 33431. Vol. 1, pp. 61.

Kansouh, A. M. and A. G. Zakher (2011). Gene action and combining ability in tomato (Lycpersicon esculentum Mill.) by line $\mathrm{x}$ tester analysis. $\mathrm{J}$. Plant Prod, Mansoura Univ., 2(2): 213-227.

Kempthorne, O. (1957). An introduction to Genetic Statistics. John Wiley and Sons, New York.

Metwally, E.; A. EL-Zawily; N. Hassan and O. Zanata (1996). Inheritance of fruit set and yield of tomato under high temperature conditions in Egypt. $1^{\text {st }}$ Egypt-Hung. Hort. Conf., Vol. 1. 112-122.

Mondal, C.; S. Sarkar and P. Hazara (2009). Line $x$ tester analysis of combining ability in tomato (Lycopersicon esculentum Mill.). J. Crop and Weed, 5(1): 53-57.

Patel, J. A.; M. J. Patel; R. R. Acharya; A. S. Bhanvadia and M. K. Bhalala (2004). Hybrid vigour, gene action and combining ability in chili (Capsicum annum L.) hybrids involving male sterile lines. Indian J.Genet. 64(1): 81-82.

Saeed, A. S. C.; A. A. Khan; B. Sadia and L. A. Khan (2008). Analysis of combining ability for yield, yield components and quality characters in tomato (Lycpersicon esculentum Mill.). J. Agric. Res., 46 (4): 325-332.

Shalaby, T. A (2013). Mode of gene action, heterosis and inbreeding depression for yield and its components in tomato (Solanum lycopersicum L.). Sci. Hort.164:540-543.

Sharma, D. K.; D. R. Chaudhary and P. P. Sharma (1999). Line $x$ tester analysis for study of combining ability of quantitative traits in tomato. Indian J. Horticulture 56(2): 163-168.

Singh, R. K. and B. D. Chaudhary (1995). Biometrical methods in quantitative genetic analysis. Kalyani Publishers, New Delhi, India.

Solieman. T. H. I.; M. A. H. EL-Gabry and A. I. Abido (2013). Heterosis, potence ratio and correlation of some important characters in tomato (Solanum lycopersicum L.). Sci. Hort. 150, 25 - 30.

Tiwari, R. N. and B. Choudhury (1986).Solanaceous Crops, Tomato. In: Vegetable Crops in India T. K. Bose and M.G. Som (eds), Naya Prokash, Calcutta. pp 248-290. 
الفعل الجيني والقدرة علي التآلف لبعض هجن الطمـاطم المنزرعة في العروة الصيفية

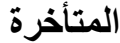

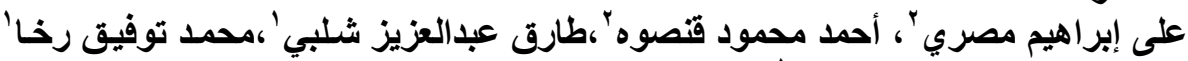

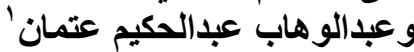

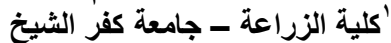
'شعبة بحوث الخضر ـ معهذ بحوث البساتين ـ مركز البحوث الزراعية

اجريت هذه الدراسه بكلية الزراعة جامعة كفر الثيخ وتم تتفيذ التجارب الحقلية بمركز

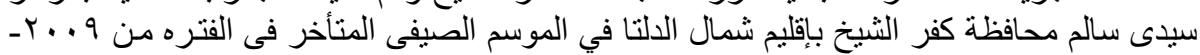

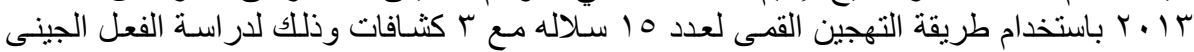

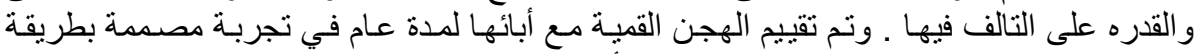

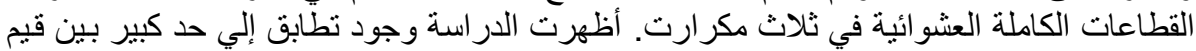

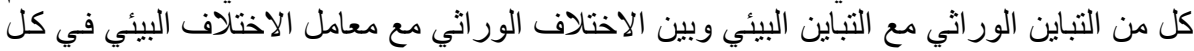

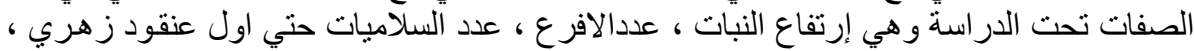

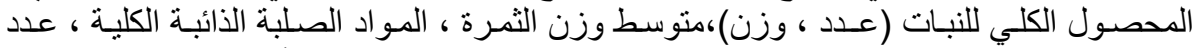

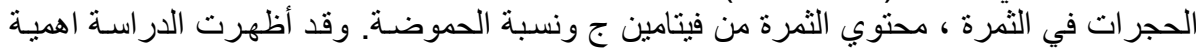

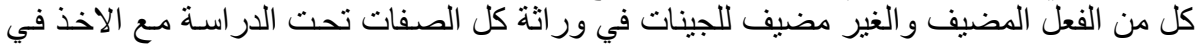

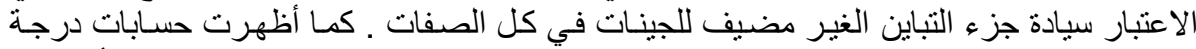

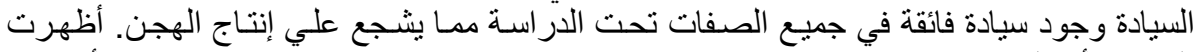

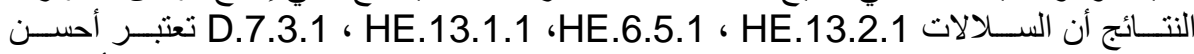

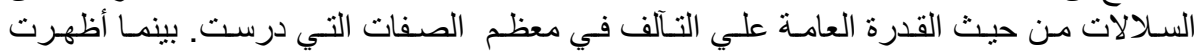

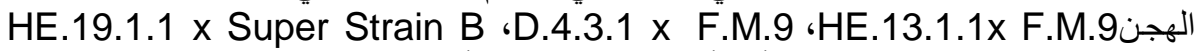
D.2.1.2x Super Strain B, التآلف لمعظم الصفات التي درست مما يشجع علي الثروع في إنتاج الطماطم الهجين. 